\title{
Adult longevity and its relationship with conservation status in European butterflies
}

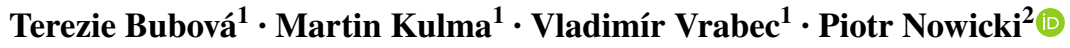

Received: 17 June 2016 / Accepted: 16 November 2016 / Published online: 21 November 2016

(C) The Author(s) 2016. This article is published with open access at Springerlink.com

\begin{abstract}
Many European butterfly species are currently experiencing serious declines, and may be threatened with extinction. Nevertheless, due to limited knowledge on the species biology and ecology, detailed assessments of endangerment level are not possible, and instead identifying species of conservation concern has to rely on proxies. Earlier studies suggested several characteristics, including host plant specificity, overwintering stage, patch size requirements or mobility, as potentially useful indicators of butterfly species vulnerability, but the usefulness of adult longevity in this respect has not been considered so far. Based on the information gathered through an extensive literature search we investigated the relationship between adult life span, flight period length or the temporal fragmentation index calculated as the ratio of the two parameters, and conservation status of European butterflies. We found that the species classified in one of the IUCN conservation concern categories (i.e. Endangered, Near Threatened, or Vulnerable) lived shorter as adults and were characterised by higher values of the temporal fragmentation index, while there was no particular pattern concerning flight period length. We believe that the apparent effects detected reflect the fact that shorter adult life span, and thus increased temporal fragmentation, in combination with protandry, i.e. earlier emergence of males, decrease individual chances of finding mating partners. Such a situation leads
\end{abstract}

Piotr Nowicki

piotr.nowicki@uj.edu.pl

1 Department of Zoology and Fisheries, Czech University of Life Sciences, Kamýcká 129, Suchdol, 16521 Prague 6, Czech Republic

2 Institute of Environmental Sciences, Jagiellonian University, Gronostajowa 7, 30-387 Kraków, Poland to lower effective population size and reduced viability, especially in the case of small populations. All concerned, the investigated parameters reflecting adult longevity may serve as 'early warning' indicators, helping to flag-up butterfly species possibly at risk.

Keywords Extinction risk $\cdot$ Flight period $\cdot$ Life span · Species vulnerability $\cdot$ Temporal fragmentation $\cdot$ Threat level

\section{Introduction}

Butterfly populations in Europe have declined drastically in recent decades (Thomas et al. 2004; EEA 2011). These negative trends have prompted the launching of numerous programmes for butterfly conservation (Warren and Bourn 2011). However, for effective conservation, it is necessary to properly identify species threatened with extinction, and Red Lists are compiled for this purpose. Assessments of species positions on such lists should ideally be based on thorough knowledge of their biology and ecology and how these affect the species vulnerability to threats (Margules and Pressey 2000; Mattila et al. 2006). Despite the fact that butterflies comprise one of the most studied invertebrate groups, such knowledge is nevertheless available for only a very limited number of butterfly species (van Swaay 2002; Wenzel et al. 2006; Müller et al. 2010). Therefore, for their successful conservation, it is important to identify traits that predispose butterfly species to extinction risk (Mattila et al. 2006). Life history traits and/or ecological characteristics could be used as indicators of potential vulnerability to threats as many of these characteristics are common among species of conservation concern (Statzner et al. 2001; Mattila et al. 2006; Nylin and Bergström 2009). 
Studies conducted to date have identified a wide range of butterfly characteristics that can potentially act as proxies for extinction risk. One of the most commonly addressed aspects in this respect is the division into generalists and specialists (Nylin and Bergström 2009; Ali and Agrawal 2012; Bartoňová et al. 2014). The latter group includes a disproportionally high number of threatened species due to their stricter habitat and host plant requirements (Hodgson 1993; Purvis et al. 2000; Fontaine et al. 2007). Another well-established pattern relates to life history and voltinism, where univoltine species and/or those overwintering in the egg or larval stage are more susceptible to climate change, which has recently become one of the most serious drivers of butterfly declines (Hodgson 1993; Conrad et al. 2004; Mattila et al. 2006; Nylin and Bergström 2009). In addition, low mobility was typically reported for threatened butterflies (Kotiaho et al. 2005; Mattila et al. 2006; Nylin and Bergström 2009; Habel et al. 2015). This is not surprising, because less mobile species with low colonization success rates are more vulnerable to the effects of habitat fragmentation, which is nowadays a crucial threat for butterflies (Thomas 1995; Novacek and Cleland 2001; Baguette and Schtickzelle 2006; Franzen and; Johannesson 2007). Also as a consequence of habitat fragmentation, butterflies with greater patch size requirements are highly represented among species of conservation concern (Cowley et al. 1999; Kotiaho et al. 2005; Baguette and Stevens 2013).

It has recently been pointed out that the extinction risk of butterfly populations is likely to depend not only upon classic spatial fragmentation of their habitats, but also upon their fragmentation over time (Nowicki et al. 2005b). The latter derives from the fact that the individual life span of the adult butterflies is usually much shorter than is the length of adult occurrence season dubbed as the flight period. Consequently, groups of individuals from different parts of a season do not have the chance to mate with one another. This problem is further exacerbated by protandry, i.e. earlier emergence of males in the season as compared with females, which is typical for butterflies (Wiklund and Fagerström 1977). The extent of and a temporal fragmentation (sensu Nowicki et al. 2005b) depends upon adult life span and flight period length and so it is highly variable among butterflies. Surprisingly, the effects of temporal fragmentation on butterfly species extinction risk have not been investigated so far.

In the present study we evaluated the relationships between adult life span, flight period length, and a temporal fragmentation index (defined as the ratio of flight period length to adult life span) on one hand, and the species conservation status, as reported in the European Red List (van Swaay et al. 2010), on the other hand. Butterflies that have short life spans and long flight season length will have fewer opportunities for males and females representing different daily cohorts to meet together (Nowicki et al. 2005b). Consequently, we hypothesised that a higher level of threat should be associated with: (a) shorter adult life span; (b) longer flight period length; and (c) higher values of the temporal fragmentation index. We tested the above hypotheses using the data gathered through an extensive literature review.

\section{Methods}

\section{Literature search}

In order to gather information on adult life span and flight period length in butterflies, we searched for mark-recapture studies (which typically assess both these parameters) within the following databases: ISI Web of Science (http://apps.webofknowledge.com/), Scopus (http://www. scopus.com/home.url), and Google Scholar (http://scholar. google.com/). We used "(re)capture" and "butterfly/butterflies" or "Lepidoptera" as the searched keyword combinations. We restricted our search results to only European species, because relatively little information was available for all others, with the slight exception of a small number of North American species. We also utilised relevant grey literature on the subject, in particular academic theses or reports known to us.

We considered only adult life span data originating from field studies, and thus we excluded literature on adult life span measured in controlled conditions, i.e. physiological longevity. This is because when butterflies are raised in enclosures or laboratories, their recorded longevity is known to overestimate the life span actually achieved in nature (Karlsson and Wiklund 2005; Nowicki et al. 2005b). We likewise excluded mark-recapture estimates of butterfly residence time assessed in clearly open populations, which are subject to substantial emigration and thus considerably underestimate butterfly longevity (Nowicki et al. 2005a). An exception was made for the cases in which the emigration rate could be estimated and accounted for, e.g. using the Virtual Migration model (Hanski et al. 2000). Consequently, we believe that the life span estimates we used in our study represent true adult longevities and not just adult residence times within the surveyed populations.

Quite often the literature sources did not explicitly report adult life span but instead they gave adult survival rate estimates. In such cases we converted survival rate $(\phi)$ into adult life span $(e)$ using the following formula: $e=(1-\phi)^{-1}-0.5$ (Nowicki et al. 2005b). Whenever the studies reported adult life span or survival estimates for males and females separately, we used the mean of the two values because they typically differed rather little, i.e. by 
less than $10 \%$. It should be noted that adult life span values provided by mark-recapture studies are restricted to a single season, and thus they do not account for the fact that certain individuals flying during the season might also be on the wing in the previous or in the following year in species overwintering as adults. Nevertheless, due to the high mortality of overwintering adults such individuals are relatively few. Furthermore, their existence does not undermine the usefulness of single-season data for our study, in which adult life span is understood as the time during which an adult flies and breeds within a single generation, and not as its total life expectancy, including the period of inactive overwintering.

Regarding flight period length, we calculated it as the total number of days of adult occurrence inclusive of the first and last day. Thus, for example, a flight period from 1 to 30 July corresponds to a length of 30 days (and not 29 days). We excluded the studies that did not cover the entire flight period, which was either explicitly mentioned by the authors or was clear from the reported results, with relatively high daily numbers of individuals recorded at the beginning or the end of the study period. In a few cases, we also used information on flight period length from studies other than mark-recapture surveys, e.g. behavioural observations conducted from the very start to the very end of the season. On the other hand, we decided not to use the information on flight period provided by several general books on butterflies (e.g. Settele et al. 1999; Beneš et al. 2002). Even though such information was easily available for most European species, it turned out to be too superficial to be applicable in our analyses. Specifically, the information was given in the form of general statements, mentioning that e.g. species X flies from early July to mid-August, thus allowing only very coarse assessments of flight period length with margins of error of as much as 10-15 days.

\section{Data handling and analysis}

The extent of temporal fragmentation was calculated as the ratio between flight period length and average adult life span, both measured in days. In the case of studies spanning several years (e.g. Schtickzelle et al. 2002; Nowicki et al. 2009), we treated the data from each year separately. In making the calculations, we endeavoured to use data on life span and flight period length from the same population and year. This usually was possible because most mark-recapture studies reported both. Otherwise, we paired together data on adult life span and flight period from the closest-lying locations, but in rare cases these locations were quite distant from one another and represented different biogeographic regions. For multivoltine species, we relied on information provided by studies conducted on the first generation whenever possible. This is because the population size of the first generation is generally much smaller than those of later generations and it is thus critical for species persistence, and furthermore the occurrence of later generations is sometimes facultative (Franzen and Johannesson 2007; Fric et al. 2010; Nabielec and Nowicki 2015).

For species with more than one record available, we calculated median values of adult life span, flight period length, and temporal fragmentation index and used them in the subsequent analyses, since the distributions of records were often non-normal (right-skewed). In turn, it is worth noting that the distribution of median values among species was normal for all of the three parameters considered.

For the purpose of the analyses, we adopted the Red List status of European butterflies in accordance with van Swaay et al. (2010). Despite our original expectations, the sample sizes of species for which we were able to gather data were small in the three conservation concern categories, i.e. Endangered (EN), Vulnerable (VU), and Near Threatened (NT). We therefore decided to pool these into a single 'conservation concern' category (CC) and analyse it against the species categorized as Least Concern (LC).

We analysed the relationship between adult life span, flight period length or temporal fragmentation index, and conservation status (CC vs. LC, dichotomous dependent variable) using logistic regression analysis. For each predictor, we conducted two separate analyses, using the full data set gathered as well as what we term a 'core data set'. The core data set excluded species for which data quality was problematic for various reasons. These included cases of (a) species for which data on adult life span and flight period length came from distant populations, representing different biogeographic regions; (b) species for which only the data for the second generation was available; and (c) Maculinea alcon, the conservation status of which is questionable, apparently due to its uncertain systematic status, with two distinct forms existing, namely $M$. alcon 'alcon' and M. alcon 'rebeli' (Als et al. 2004; Steiner et al. 2005; Pecsenye et al. 2007; Sielezniew et al. 2012). It is classified as LC by van Swaay et al. (2010), however many authors regard both forms to be under threat in Europe (WallisDeVries 2004; Tartally et al. 2008; Czekes et al. 2014).

Obviously, a common problem with cross-species analyses is that records for related species may not be fully independent from one another. The standard solution in such cases is controlling for phylogenetic autocorrelations (Martins and Hansen 1996). However, this was not possible in our study, because a full phylogenetic tree with scalable inter-specific distances is not yet available for European butterflies (cf. Cowley et al. 2001; Bartoňova et al. 2014). Therefore, in order to verify the risk of phylogenetic autocorrelation biases, we instead applied the intraclass correlation coefficients (Stanish and Taylor 1983; Lessells and 
Boag 1987) to test for potential repeatability of our records within species as well as higher taxa, namely tribes, subfamilies, and families (but not at the genus level, because we rarely had data for more than one species per genus). The testing yielded significant results for species (life span: $r_{I}=0.7379, P<0.0001$; flight period length: $r_{I}=0.5513$, $P<0.0001$ ), but not for any higher taxa (life span: $r_{I}=0.0539, P=0.6691$ for tribes; $r_{I}=0.1166, P=0.4962$ for subfamilies; $r_{I}=0.0408, P=0.6386$ for families; flight period length: $r_{I}=0.1922, P=0.2835$ for tribes; $r_{I}=0.1401$, $P=0.4468$ for subfamilies; $r_{I}=0.1312, P=0.4213$ for families). Such an outcome indicates that our data records were highly repeatable within species, but fairly independent among them. This, in combination with the fact that despite a relatively small sample size we managed to gather data for a wide range of European butterfly species, makes us believe that the results of our analyses are not biased by potential phylogenetic autocorrelations.

\section{Results}

We successfully gathered relevant information for 50 species of European butterflies, including 4 classified as EN, 5 as VU, and 6 as NT, as well as 35 species classified as LC (Table 1). The average adult life span of these species ranged from ca. 2.5 to 15 days. The flight period length was between 20 and 50 days in most cases, although some clear outliers could also be noticed. The shortest adult occurrence season was reported for Pseudophilotes bavius (median value of 16.5 days), whereas in satyrid butterflies it sometimes approached or exceeded 70 days (in Maniola jurtina and Coenonympha pamphilus respectively). There was no apparent correlation between flight period length and adult life span (Pearson's correlation: $r=0.1794$, $P=0.2125$ ), and consequently the ratio of the two parameters, which we defined as the temporal fragmentation index, varied greatly from ca. 2 to more than 12 (Table 1).

As indicated by Red List categories, extinction risk generally increased with increasing adult life span (Fig. 1a). Similarly, butterflies in the three categories collectively characterized as $\mathrm{CC}$ had higher temporal fragmentation index values (Fig. 1c). On the other hand, there was no clear pattern concerning flight period length, which turned out to be slightly elevated among NT species. The latter result was partly due to strong variation within this particular group (Fig. 1b).

The logistic regression analyses confirmed the above patterns, revealing significant relationships with species conservation status (CC vs. LC) in the case of adult life span and temporal fragmentation index, but no effect whatsoever for flight period length (Table 2). It is noteworthy that the effect of adult longevity and temporal fragmentation increased (despite considerably smaller sample sizes) when the analyses were restricted to the core data set, thus excluding species for which the quality of the data gathered was problematic. The threshold value for adult life span at which a species had 50\% probability of being listed in one of the CC categories was 3.53 days for the full data set and 4.31 days for the core data set. In the case of temporal fragmentation index, the respective thresholds were 9.19 and 8.01 .

\section{Discussion}

The selection of species on which we based our investigation may not be fully representative for the whole spectrum of European butterflies. In particular, an underrepresented group are the species from Mediterranean region as well as from northern Europe, the conservation status of which is potentially less related to adult longevity and more to the life history parameters beyond the scope of the present study, such as wintering stage and voltinism (Mattila et al. 2006; Nylin and Bergström 2009). Another limitation of our database is the fact that it lacked very common species, mostly of Nymphalidae and Pieridae families, which are neglected in mark-recapture studies, apparently because of the lack of scientific and conservation interest in them. Nevertheless, based on anecdotal information such species are reported to have long-living adults (Settele et al. 1999; Beneš et al. 2002), and thus we believe that their inclusion would have actually strengthened the outcome of our analyses.

Our results indicated the existence of clear relationships between adult life span and temporal fragmentation index on one hand and conservation status of European butterflies on the other. Moreover, the relationships proved to be significant, regardless of whether the full data set or the core data set was used, which increases our confidence in these findings. In contrast, butterfly conservation status was not linked in any way to flight period length as defined in our study.

Butterfly adult life span is a part of an adaptive life history which involves mating and egg laying strategy (Carey 2001; Beck and Fiedler 2009). The average life span reported in our study typically reached only a few days. Such a short life span implies that the mating must take place shortly after eclosion to minimise delay and allow most of the females to oviposit their eggs before they die (Scott 1973; Beck and Fiedler 2009). Hence, in species with short life spans adult butterflies have a very narrow time window to copulate. Adult life span also affects realised fecundity, i.e. the number of eggs laid, which in turn can have a critical impact on population viability (Fischer et al. 2006; Pijpe 2007; Haeler et al. 2014). Low quantities 
Table 1 Summary information on adult life span, flight period length, and the temporal fragmentation index (i.e. ratio of flight period length to adult life span) gathered for European butterflies

\begin{tabular}{|c|c|c|c|c|c|}
\hline Species & Status & Life span (days) & Flight period (days) & Temporal fragmentation & Sources \\
\hline Colias myrmidone $\mathrm{a}^{\mathrm{a}}$ & EN & $3.54(3.32-3.75)$ & $26(21-31)$ & $7.47(5.60-9.34)$ & Szentirmai et al. (2014) \\
\hline Lycaena helle & EN & $7.19(5.45-7.83)$ & $39(29-64)$ & $5.87(3.87-8.90)$ & $\begin{array}{l}\text { Fischer et al. (1999), Bauer- } \\
\text { feind et al. (2009), Reymond } \\
\text { (2014), Turlure et al. (2014), } \\
\text { Nabielec and Nowicki (2015) }\end{array}$ \\
\hline Phengaris (=Maculinea) arion & EN & $3.53(3.07-4.26)$ & $37(32-39)$ & $10.28(9.15-10.92)$ & Bonelli et al. (2013) \\
\hline Coenonympha oedippus & EN & $3.00(2.50-4.20)$ & $27.5(18-28)$ & $7.98(6.67-10.00)$ & Örvössy et al. (2013) \\
\hline Phengaris $(=$ Maculinea) teleius & $\mathrm{VU}$ & $3.01(1.61-4.16)$ & $38(28-56)$ & $12.01(9.12-40.00)$ & $\begin{array}{l}\text { Nowicki et al. (2005a, b, 2009, } \\
\text { 2014), Vodă et al. (2010) }\end{array}$ \\
\hline Euphydryas maturna & $\mathrm{VU}$ & $6.53(4.75-8.30)$ & $42.5(36-49)$ & $7.33(4.34-10.32)$ & $\begin{array}{l}\text { Wahlberg et al. (2002), } \\
\text { Konvička et al. (2005) }\end{array}$ \\
\hline Lopinga achine & $\mathrm{VU}$ & $6.30(5.95-6.64)$ & $28(25-31)$ & $4.43(4.20-4.67)$ & $\begin{array}{l}\text { Bergman and Landin (2002), } \\
\text { Streitberger et al. (2012) }\end{array}$ \\
\hline Coenonympha tullia & $\mathrm{VU}$ & $3.05(2.80-3.30)$ & $24.5(21-28)$ & $7.99(7.50-8.48)$ & $\begin{array}{l}\text { Turner (1963), Warren (1992), } \\
\text { Komonen et al. (2004) }\end{array}$ \\
\hline Erebia sudetica & $\mathrm{VU}$ & 4.00 & 29 & 7.25 & Nowicki et al. (2005a) \\
\hline Thymelicus acteon $^{\mathrm{b}}$ & NT & 7.00 & 41 & 5.86 & $\begin{array}{l}\text { Thomas (1983), Buszko and } \\
\text { Masłowski (2008) }\end{array}$ \\
\hline Parnassius mnemosyne & NT & $9.06(5.05-11.15)$ & $51(31-51)$ & $5.66(4.57-10.10)$ & $\begin{array}{l}\text { Schmidt (1989), Seufert } \\
\text { (1990), Konvička and Kuras } \\
\text { (1999) }\end{array}$ \\
\hline Parnassius apollo & NT & $3.73(3.20-4.26)$ & $29(25-33)$ & $8.08(5.87-10.30)$ & $\begin{array}{l}\text { Brommer and Fred (1999), } \\
\text { Komonen et al. (2004), Fred } \\
\text { et al. (2006) }\end{array}$ \\
\hline Iolana iolas & NT & $5.88(3.63-8.12)$ & $49.5(49-50)$ & $9.83(6.16-13.50)$ & $\begin{array}{l}\text { Rabasa et al. }(2005,2007) \text {, } \\
\text { Heer et al. }(2013)\end{array}$ \\
\hline Phengaris (=Maculinea) nausithous & NT & $2.84(2.02-5.74)$ & $40(23-56)$ & $12.64(4.36-23.76)$ & $\begin{array}{l}\text { Pfeifer et al. (2000, 2007), } \\
\text { Nowicki et al. (2005a, b, } \\
\text { 2014), Vodă et al. (2010) }\end{array}$ \\
\hline Euphydryas desfontainii & NT & 5.55 & 36 & 6.49 & Pennekamp et al. (2014) \\
\hline Pyrgus sidae & $\mathrm{LC}$ & 9.20 & 25 & 2.72 & Hernándes-Roldán et al. (2009) \\
\hline Hesperia comma & $\mathrm{LC}$ & $4.40(3.00-10.30)$ & $35(23-50)$ & $7.95(2.23-15.63)$ & $\begin{array}{l}\text { Thomas (1983), Komonen } \\
\text { et al. (2004), Soulsby and } \\
\text { Thomas (2012) }\end{array}$ \\
\hline Zerynthia polyxena & $\mathrm{LC}$ & $5.28(4.40-6.17)$ & $29(20-38)$ & $5.94(3.24-8.64)$ & $\begin{array}{l}\text { Örvössy et al. (2005), Batáry } \\
\text { et al. (2008), Celik (2012) }\end{array}$ \\
\hline Leptidea sinapis $^{\mathrm{a}}$ & $\mathrm{LC}$ & $8.35(6.50-10.20)$ & $38.5(33-44)$ & $5.00(3.24-6.77)$ & $\begin{array}{l}\text { Warren et al. (1986), Komonen } \\
\text { et al. (2004), Friberg et al. } \\
\text { (2008) }\end{array}$ \\
\hline Leptidea reali ${ }^{\mathrm{a}}$ & $\mathrm{LC}$ & 7.60 & 44 & 5.79 & Friberg et al. (2008) \\
\hline Anthocharis cardamines & $\mathrm{LC}$ & $6.95(5.60-8.30)$ & $28.5(21-34)$ & $4.30(2.53-6.07)$ & $\begin{array}{l}\text { Courtney and Duggan (1983), } \\
\text { Dempster (1997) }\end{array}$ \\
\hline Lycaena virgaureae & LC & $6.43(6.20-6.65)$ & $31(29-33)$ & $4.84(4.36-5.32)$ & $\begin{array}{l}\text { Fjellstad (1998), Komonen } \\
\text { et al. (2004), Haaland (2015) }\end{array}$ \\
\hline Lycaena hippothoe & $\mathrm{LC}$ & $9.60(7.00-10.00)$ & $28(28-32)$ & $2.92(2.80-4.57)$ & $\begin{array}{l}\text { Fischer (1998), Fischer and } \\
\text { Fiedler (2001), Komonen } \\
\text { et al. (2004) }\end{array}$ \\
\hline Satyrium w-album ${ }^{\mathrm{b}}$ & $\mathrm{LC}$ & 6.90 & 28 & 4.06 & $\begin{array}{l}\text { Warren (1992), Komonen et al. } \\
\text { (2004) }\end{array}$ \\
\hline Cupido minimus $^{\mathrm{b}}$ & LC & 15.00 & 31 & 2.07 & $\begin{array}{l}\text { Morton (1985), Komonen et al } \\
\text { (2004) }\end{array}$ \\
\hline Pseudophilotes bavius & $\mathrm{LC}$ & $2.80(2.40-5.40)$ & $16.5(12-28)$ & $5.47(2.50-11.67)$ & Crişan et al. (2014) \\
\hline Phengaris (=Maculinea) alcon ${ }^{\mathrm{c}}$ & LC & $2.44(1.62-5.98)$ & $29(18-60)$ & $11.88(5.59-29.27)$ & $\begin{array}{l}\text { Seufert (1993), Nowicki et al. } \\
\text { (2005a, 2009), Timuș et al. } \\
\text { (2013) }\end{array}$ \\
\hline Plebejus argus & $\mathrm{LC}$ & $3.35(3.20-3.50)$ & $30(20-40)$ & $9.11(5.71-12.50)$ & $\begin{array}{l}\text { Warren (1992), Lewis et al. } \\
\text { (1997), Cormont et al. } \\
\text { (2011) }\end{array}$ \\
\hline
\end{tabular}


Table 1 (continued)

\begin{tabular}{|c|c|c|c|c|c|}
\hline Species & Status & Life span (days) & Flight period (days) & Temporal fragmentation & Sources \\
\hline Aricia eumedon $^{\mathrm{b}}$ & $\mathrm{LC}$ & 3.59 & 19 & 5.30 & $\begin{array}{l}\text { Seufert (1993), Komonen et al. } \\
\text { (2004) }\end{array}$ \\
\hline Polyommatus icarus ${ }^{\mathrm{a}}$ & LC & $4.40(3.40-5.40)$ & $26(18-34)$ & $5.80(5.29-6.30)$ & $\begin{array}{l}\text { Dowdeswell et al. (1940), } \\
\text { Scott (1973), Komonen et al. } \\
\text { (2004) }\end{array}$ \\
\hline Polyommatus bellargus & $\mathrm{LC}$ & $9.10(8.10-10.10)$ & $26.5(24-29)$ & $2.98(2.38-3.58)$ & Davis et al. (1958) \\
\hline Polyommatus coridon & $\mathrm{LC}$ & $5.52(3.70-8.70)$ & $56.5(24-63)$ & $10.79(4.21-14.86)$ & $\begin{array}{l}\text { Davis et al. (1958), Nowicki } \\
\text { et al. (2005a), Schmitt et al. } \\
\text { (2006) }\end{array}$ \\
\hline Argynnis paphia ${ }^{\mathrm{b}}$ & $\mathrm{LC}$ & 11.50 & 38 & 3.30 & $\begin{array}{l}\text { Magnus (1954), Komonen } \\
\text { et al. (2004) }\end{array}$ \\
\hline Argynnis aglaja & $\mathrm{LC}$ & 8.20 & 58 & 7.07 & Zimmermann et al. (2009) \\
\hline Brenthis ino & LC & $9.74(5.70-13.79)$ & $40.5(35-46)$ & $5.30(2.54-8.07)$ & $\begin{array}{l}\text { Zimmermann et al. (2005), } \\
\text { Fric et al. (2010) }\end{array}$ \\
\hline Boloria eunomia & $\mathrm{LC}$ & $8.23(3.00-11.55)$ & $35.5(26-45)$ & $4.32(2.68-11.00)$ & $\begin{array}{l}\text { Schtickzelle et al. (2002), } \\
\text { Turlure et al. (2010) }\end{array}$ \\
\hline Boloria euphrosyne & LC & $9.00(5.97-11.10)$ & $29(24-32)$ & $3.39(2.61-4.02)$ & $\begin{array}{l}\text { Baguette and Neve (1994), } \\
\text { Komonen et al. (2004), Al } \\
\text { Dhaheri (2009) }\end{array}$ \\
\hline Boloria aquilonaris & $\mathrm{LC}$ & 4.26 & 21 & 4.93 & Turlure et al. (2010) \\
\hline Euphydryas aurinia & $\mathrm{LC}$ & $6.40(2.24-15.37)$ & $31(15-42)$ & $3.16(2.60-12.95)$ & $\begin{array}{l}\text { Munguira et al. (1997), Wahl- } \\
\text { berg et al. (2002), Anthes } \\
\text { et al. (2003), Komonen et al. } \\
\text { (2004), Schtickzelle et al. } \\
\text { (2005), Fric et al. (2010), } \\
\text { Zimmermann et al. (2011), } \\
\text { Casacci et al. (2015) }\end{array}$ \\
\hline Melitaea cinxia & $\mathrm{LC}$ & 5.80 & 33 & 5.69 & Wahlberg et al. (2002) \\
\hline Melitaea Didyma & $\mathrm{LC}$ & $7.00(5.50-8.00)$ & $46(30-51)$ & $5.75(5.45-7.29)$ & Vogel and Johannesen (1996) \\
\hline Melitaea diamina & LC & $8.59(6.35-10.61)$ & $29(29-51)$ & $4.57(3.38-4.81)$ & $\begin{array}{l}\text { Hanski et al. (2000), Wahlberg } \\
\text { et al. (2002), Fric et al. } \\
\text { (2010) }\end{array}$ \\
\hline Melitaea athalia & $\mathrm{LC}$ & $10.00(5.45-11.26)$ & $35(30-55)$ & $4.88(3.50-5.50)$ & $\begin{array}{l}\text { Warren (1987), Wahlberg et al. } \\
\text { (2002), Fric et al. (2010), } \\
\text { Cormont et al. (2011) }\end{array}$ \\
\hline Pararge aegeria $^{\mathrm{a}}$ & $\mathrm{LC}$ & 9.50 & 23 & 2.42 & $\begin{array}{l}\text { Warren (1992), Komonen et al } \\
\text { (2004) }\end{array}$ \\
\hline Lasiommata megera $^{\mathrm{a}}$ & $\mathrm{LC}$ & 4.20 & 40 & 9.52 & $\begin{array}{l}\text { Parr et al. (1968), Harker and } \\
\text { Shreeve (2008) }\end{array}$ \\
\hline Coenonympha pamphilus ${ }^{\mathrm{a}}$ & $\mathrm{LC}$ & 7.30 & 76 & 10.41 & Wickman (1985) \\
\hline Aphantopus hyperantus & $\mathrm{LC}$ & $3.95(3.60-4.29)$ & $36.5(35-38)$ & $9.29(8.86-9.72)$ & $\begin{array}{l}\text { Sutcliffe et al. (1997), Soulsby } \\
\text { and Thomas (2012) }\end{array}$ \\
\hline Maniola jurtina & $\mathrm{LC}$ & $6.55(6.51-10.83)$ & $67(51-78)$ & $7.84(6.19-11.91)$ & $\begin{array}{l}\text { Tudor and Parkin (1979), } \\
\text { Brakefield (1982), Lörtscher } \\
\text { et al. (1997), Cormont et al. } \\
\text { (2011) }\end{array}$ \\
\hline Erebia aethiops & $\mathrm{LC}$ & 6.50 & 33 & 5.08 & Slámova et al. (2013) \\
\hline Minois dryas & $\mathrm{LC}$ & $4.47(3.50-6.74)$ & $25.5(19-32)$ & $5.17(4.75-6.75)$ & $\begin{array}{l}\text { Pellet and Gander (2009), } \\
\text { Bilnicki (2015) }\end{array}$ \\
\hline
\end{tabular}

Whenever more than one record was available for a species, we present the median with the range (min-max) in parentheses. Conservation status follows the European Red List of Butterflies (van Swaay et al. 2010): $E N$ endangered, $V U$ vulnerable, $N T$ near threatened, $L C$ least concern. Superscripts indicate species which were excluded from the core data set used in the analyses for various reasons

${ }^{a}$ Data available only for the second or third generation

${ }^{b}$ Data on adult life span and flight period length came from different regions

${ }^{\mathrm{c}}$ Questionable conservation status—see Methods for the rationale 

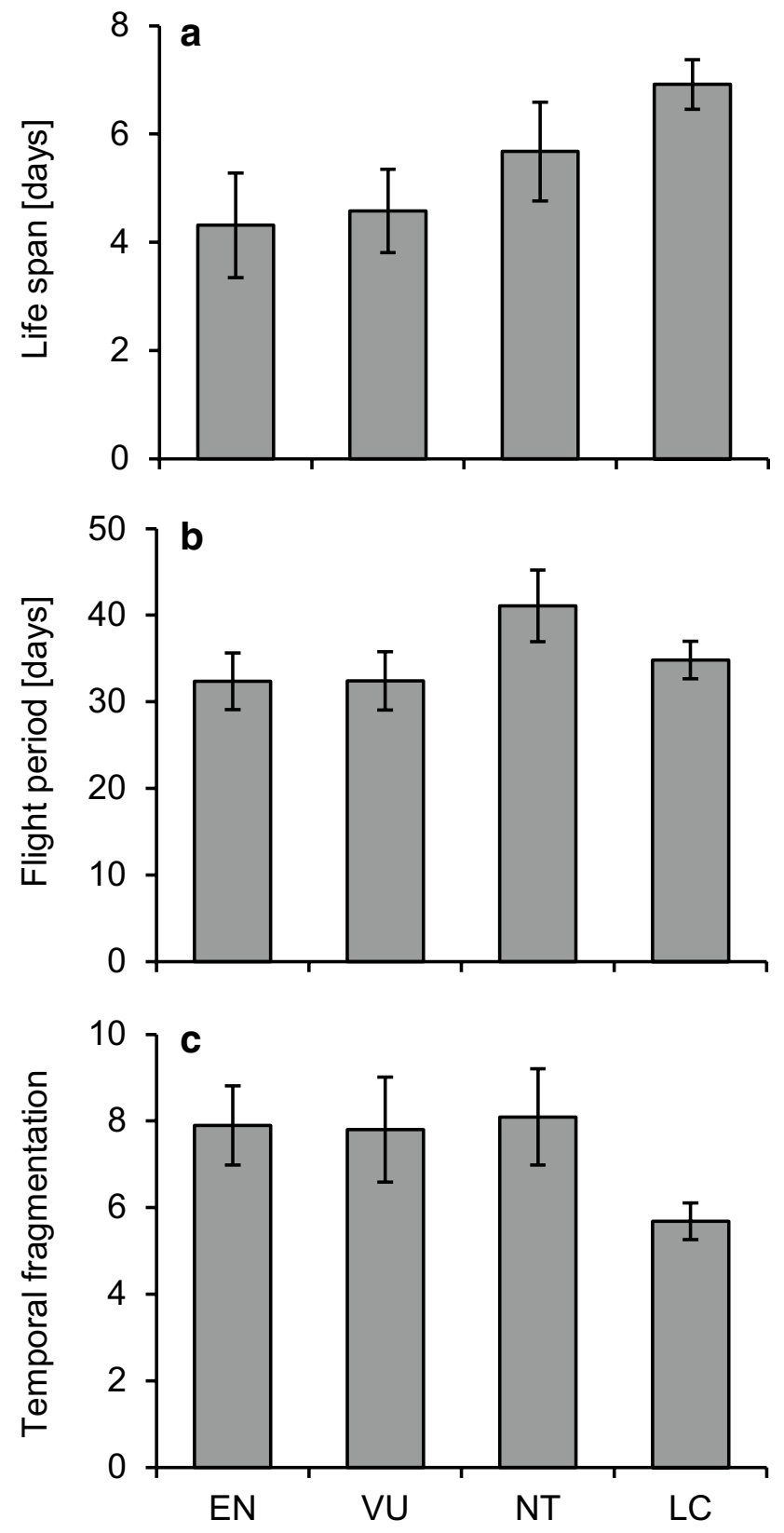

Conservation status

Fig. 1 Adult life span (a), flight period length (b), and temporal fragmentation index (c) in relation to the conservation status of European butterflies ( $E N$ endangered, $V U$ vulnerable, $N T$ near threatened, $L C$ least concern). The values shown represent means (with their SEs) across all the investigated species in each category. Different conservation concern categories (EN, VU, NT) are treated separately only for the graphic presentation, but they were pooled together in the analyses (see Table 2)

of oviposited eggs over the long term are bound to result in population decline. It is thus not surprising that the results of our study confirmed that short life span corresponds to higher threat level in European butterfly species.
Alternative hypotheses explaining the relationship between adult life span or temporal fragmentation index and conservation status involve mobility and predation. Since both emigration probability and movement distance are typically time-dependent (Hanski et al. 2000), shortlived butterflies may be expected to emigrate in lower numbers and move shorter distance throughout their adult lifetime. Species with such characteristics are more likely to experience the negative effects of habitat fragmentation, and hence be more prone to being threatened (Kotiaho et al. 2005; Franzen and; Johannesson 2007; Habel et al. 2015), especially in the highly fragmented landscapes of Europe. However, the plausibility of the above explanation is undermined by empirical studies indicating that dispersal capabilities and butterfly life span may be negatively correlated, since investing in mobility and longevity is subject to a developmental trade-off (Hanski et al. 2006; Niitepõld and Hanski 2013).

Additionally, the better conservation status of species with long-living adults might possibly be attributed to their lower mortality due to predation. It has been reported that butterflies with anti-predator defence features (such as aposematism, eye-spots, etc.) have longer life spans, but it must be stressed that the effect of these anti-predator defences on longevity was rather weak and mostly restricted to tropical butterflies (Beck and Fiedler 2009). Furthermore, although predation on adult butterflies may sometimes be considerable, it is nonetheless of relatively little importance for population dynamics as compared with predation experienced at the egg, larval or pupal stages (Dempster 1984; Warren 1992).

An increased level of temporal fragmentation was also found to correspond to higher species vulnerability in our study. A possible explanation is that if butterflies live for only a limited part of the flight period then they may have lower chances of finding mates. These low mating opportunities are further decreased by the fact that males emerge earlier in the season than females, usually by several days, due to protandry (Pfeifer et al. 2000; Petit et al. 2001; Nowicki et al. 2005b). This phenomenon is common in insects, particularly in species for which the flight season is very long and the majority of the population occurs at the beginning of the flight season, such as is the case of the mayfly (Gibbs and Siebenmann 1996; Takemon 2000). Protandry prevents inbreeding and ensures that only strong males survive long enough to mate. Moreover, it also supports immediate female fertilisation, which minimises the risk of females dying before mating (Fagerström and Wiklund 1982; Zonneveld and Metz 1991; Zonneveld 1992; Morbey and Ydenberg 2001).

Although all the aforementioned effects are considered positive, some negative consequences of protandry are also known. Since a fraction of males may not survive 
Table 2 Results of multiple logistic regression analyses of factors affecting conservation status (conservation concern vs. least concern) of European butterflies

\begin{tabular}{|c|c|c|c|c|c|c|}
\hline \multirow[t]{2}{*}{ Predictor } & \multirow{2}{*}{$\begin{array}{l}\text { Data set (with } \\
\text { sample size) }\end{array}$} & \multicolumn{2}{|c|}{ Parameter value $( \pm \mathrm{SE})$} & \multicolumn{3}{|c|}{ Model fit } \\
\hline & & Intercept & Estimate & $\chi^{2}$ & $P$ & $R^{2}$ \\
\hline \multirow[t]{2}{*}{ Life span } & Full $(n=50)$ & $1.29 \pm 0.91$ & $-0.37 \pm 0.16$ & 6.83 & 0.0089 & 0.27 \\
\hline & Core $(n=37)$ & $1.82 \pm 1.10$ & $-0.42 \pm 0.19$ & 6.05 & 0.0138 & 0.33 \\
\hline \multirow[t]{2}{*}{ Flight period length } & Full $(n=50)$ & $-1.12 \pm 0.98$ & $0.01 \pm 0.03$ & 0.09 & 0.7685 & 0.01 \\
\hline & Core $(n=37)$ & $-1.18 \pm 1.20$ & $0.02 \pm 0.03$ & 0.25 & 0.6192 & 0.01 \\
\hline \multirow[t]{2}{*}{ Temporal fragmentation } & Full $(n=50)$ & $-3.18 \pm 0.99$ & $0.35 \pm 0.13$ & 7.85 & 0.0051 & 0.29 \\
\hline & Core $(n=37)$ & $-3.85 \pm 1.31$ & $0.48 \pm 0.18$ & 9.44 & 0.0021 & 0.41 \\
\hline
\end{tabular}

long enough to mate with the later-emerging females, some females will consequently go unmated, and will thus be unable to lay eggs. This lost reproductive potential can significantly decrease population size and could also lead to population extinctions. The protandry effect might therefore be evolutionarily advantageous at higher population densities but, if the population density decreases, it can be harmful (Calabrese and Fagan 2004). Additionally, weather conditions could affect the proper timing of male and female emergence by up to several days (Schtickzelle et al. 2002; Robinet and Roques 2010). For instance, rainy days at the beginning of the flight period in 1983 were found to influence individual development in Euphydryas editha bayensis, resulting in the first females emerging 14 days after males, which had a clear negative effect on the population dynamics of the species (Dobkin et al. 1987; Baughman 1991). Furthermore, a high level of temporal fragmentation, namely short individual life span in relation to long flight period, in combination with protandry seriously reduced the effective population size (sensu Lande and Barrowclough 1987; Hill 1972), thus accelerating the loss of genetic variability in small populations.

In contrast to several earlier studies, which suggested that extinction risk in butterflies decreases with lengthening flight period (Komonen et al. 2004; Kotiaho et al. 2005; Franzen and; Johannesson 2007), our analyses did not reveal any link between flight period length alone and species conservation status. The most straightforward explanation for such a result could be that flight period length per se is unimportant for species extinction risk, and it only matters in combination with adult longevity. Nevertheless, we hypothesise that the situation is more complex, namely a longer time of adult occurrence has both positive and negative consequences for species viability. On the one hand, as discussed above, it increases the temporal fragmentation of butterfly populations and may reduce mating opportunities for both sexes. On the other hand, a longer flight period allows for the compensation of the negative effects of stochastic changes during the flight period such as unfavourable weather conditions, and inappropriate management interventions, e.g. inappropriate timing of meadow mowing (Cormont et al. 2011). An extended adult occurrence season improves the resilience of butterfly populations to catastrophic events such as floods or fires (cf. Konvička et al. 2002; Kajzer-Bonk et al. 2013; Nowicki et al. 2015), because only a small fraction of individuals is affected if a short-term disturbance happens during the flight period.

Our findings demonstrate that both adult life span and temporal fragmentation index may serve as useful "early warning' indicators, helping to flag-up butterfly species possibly at risk from among those for which detailed information essential for evaluating threat level is lacking. Regretfully, as our literature search implies, the estimates of adult life span and flight period length (needed for calculating temporal fragmentation index) are not readily available for most butterflies either. However, they are relatively easy to get through mark-recapture studies. These are simple to plan and conduct, and they may be carried out with the help of amateur naturalists. This gives the longevity-related parameters analysed in the present study a substantial advantage over the proxies for species vulnerability previously suggested by other authors (Kotiaho et al. 2005; Mattila et al. 2006; Nylin and Bergström 2009), such as host plant specificity, overwintering stage, patch size requirements or mobility (see Introduction for their rationale), because assessing the latter characteristics typically requires specialist expertise.

Obviously, the main drawback of mark-recapture studies is their labour-intensity. Therefore, it would be highly desirable if the information on adult longevity and flight period length could be extracted from the well-established butterfly monitoring schemes based on transect counts. Evaluating flight period length with transect counts requires increased frequency of the transect surveys, because biweekly counts, as currently adopted in most monitoring schemes (van Swaay et al. 2008), are not enough for this purpose. In turn, assessing adult longevity with transects counts appears more difficult to accomplish. Zonneveld (1991) developed a theoretical model for the estimation of life span from transect count data, but its applicability has so far been hampered by rigorous assumptions, which are difficult to meet in real world situations (Nowicki et al. 2008). Nevertheless, more recent developments based on this model, such as the Insect Count Analyzer (INCA) 
software (Longcore et al. 2003), are promising and give some hope that transect counts can be reliably used to derive butterfly life span estimates in the near future.

Acknowledgements The study was funded by the Polish National Science Centre Grant DEC-2013/11/B/NZ8/00912 and by the Internal Grant Agency of the Czech University of Life Sciences Prague (CIGA) through its Project No. 20152004. We thank Ian Fiala for improving the English of the manuscript.

Open Access This article is distributed under the terms of the Creative Commons Attribution 4.0 International License (http:// creativecommons.org/licenses/by/4.0/), which permits unrestricted use, distribution, and reproduction in any medium, provided you give appropriate credit to the original author(s) and the source, provide a link to the Creative Commons license, and indicate if changes were made.

\section{References}

Al Dhaheri SSO (2009) The ecology and conservation of the Pearl bordered Fritillary Butterfly (Boloria euphrosyne) in Scotland. Dissertation, University of Aberdeen

Ali JG, Agrawal AA (2012) Specialist versus generalist insect herbivores and plant defense. Trends Plant Sci 17:293-302

Als TD et al (2004) The evolution of alternative parasitic life histories in large blue butterflies. Nature 432:386-390

Anthes N, Fartmann T, Hermann G (2003) Wie lässt sich der Rückgang des Goldenen Scheckenfalters (Euphydryas aurinia) in Mitteleuropa stoppen? Erkenntnisse aus populationsökologischen Studien in voralpinen Niedermoorgebieten und der Arealentwicklung in Deutschland. Naturschutz Landschaftsplanung 35:279-287

Baguette M, Nève G (1994) Adult movements between populations in the specialist butterfly Proclossiana eunomia (Lepidoptera, Nymphalidae). Ecol Entomol 19:1-5

Baguette M, Schtickzelle N (2006) Negative relationship between dispersal distance and demography in butterfly metapopulations. Ecology 87:648-654

Baguette M, Stevens VM (2013) Predicting minimum area requirements of butterflies using life-history traits. J Insect Conserv $17: 645-652$

Bartoňová A, Beneš J, Konvička M (2014) Generalist-specialist continuum and life history traits of Central European butterflies (Lepidoptera) - are we missing a part of the picture? Eur $\mathbf{J}$ Entomol 111:543

Batáry P, Örvössy N, Kőrösi Á, Peregovits L (2008) Egg distribution of the southern festoon (Zerynthia polyxena) (Lepidoptera, Papilionidae). Acta Zool Acad Sci H 54:401-410

Bauerfeind SS, Theisen A, Fischer K (2009) Patch occupancy in the endangered butterfly Lycaena helle in a fragmented landscape: effects of habitat quality, patch size and isolation. J Insect Conserv 13:271-277

Baughman JF (1991) Do protandrous males have increased mating success? The case of Euphydryas editha. Am Nat 138:536-542

Beck J, Fiedler K (2009) Adult life spans of butterflies (Lepidoptera: Papilionoidea + Hesperioidea): broadscale contingencies with adult and larval traits in multi-species comparisons. Biol J Linn Soc 96:166-184

Beneš J et al (2002) Motýli České republiky: Rozšîření a ochrana I, II. SOM, Praha
Bergman KO, Landin J (2002) Population structure and movements of a threatened butterfly (Lopinga achine) in a fragmented landscape in Sweden. Biol Conserv 108:361-369

Bilnicki K (2015) Within-season population dynamics of the dryad butterfly (Minois dryas) in relation to habitat type. Bachelor Thesis, University of Kraków

Bonelli S, Vrabec V, Witek M, Barbero F, Patricelli D, Nowicki P (2013) Selection on dispersal in isolated butterfly metapopulations. Popul Ecol 55:469-478

Brakefield PM (1982) Ecological studies on the butterfly Maniola jurtina in Britain. II. Population dynamics: the present position. J Anim Ecol 51:727-738

Brommer J, Fred MS (1999) Movement of the Apollo butterfly Parnassius apollo related to host plant and nectar plant patches. Ecol Entomol 24:125-131

Buszko J, Masłowski J (2008) Motyle dzienne Polski. Wydawnictwo Koliber, Nowy Sącz

Calabrese JM, Fagan WF (2004) Lost in time, lonely, and single: reproductive asynchrony and the Allee effect. Am Nat 164:25-37

Carey JR (2001) Insect biodemography. Annu Rev Ecol 46:79-110

Casacci L et al (2015) Dispersal and connectivity effects at different altitudes in the Euphydryas aurinia complex. J Insect Conserv 19:265-277

Celik T (2012) Adult demography, spatial distribution and movements of Zerynthia polyxena (Lepidoptera: Papilionidae) in a dense network of permanent habitats. Eur J Entomol 109:217-227

Conrad KF, Woiwod IP, Parsons M, Fox R, Warren MS (2004) Longterm population trends in widespread British moths. J Insect Conserv 8:119-136

Cormont A, Malinowska AH, Kostenko O, Radchuk V, Hemerik L, WallisDeVries MF, Verboom J (2011) Effect of local weather on butterfly flight behaviour, movement, and colonization: significance for dispersal under climate change. Biodivers Conserv 20:483-503

Courtney S, Duggan A (1983) The population biology of the orange tip butterfly Anthocharis cardamines in Britain. Ecol Entomol $8: 271-281$

Cowley MJR, Thomas CD, Thomas JA, Warren M (1999) Flight areas of British butterflies: assessing species status and decline. $\mathrm{P}$ Roy Soc Lond B Bio 266:1587-1592

Cowley MJR, Thomas CD, Roy DB, Wilson RJ, Leon-Cortes JL, Gutierrez D, Bulman CR, Quinn RM, Moss D, Gaston KJ (2001) Density-distribution relationships in British butterflies. I. The effect of mobility and spatial scale. J Anim Ecol 70:410-425

Crişan A, Sitar C, Craioveanu MC, Vizauer TC, Rakosy L (2014) Multiannual population size estimates and mobility of the endemic Pseudophilotes bavius hungarica (Lepidoptera: Lycaenidae) from Transylvania (Romania). North-West. J Zool 10:S115-S124

Czekes Z, Markó B, Nash DR, Ferencz M, Lázár B, Rákosy L (2014) Differences in oviposition strategies between two ecotypes of the endangered myrmecophilous butterfly Maculinea alcon (Lepidoptera: Lycaenidae) under unique syntopic conditions. Insect Conserv Divers 7:122-131

Davis G, Frazer J, Tynan A (1958) Population numbers in a colony of Lysandra bellargus Rott. (Lepidoptera: Lycaenidae) during 1956. In: Proceedings of the Royal Entomological Society of London. Gen Entomol 1-3:31-36

Dempster JP (1984) The natural enemies of butterflies. In: VaneWright RI, Ackery PR (eds) The biology of butterflies. Academic Press, London, pp 97-104

Dempster JP (1997) The role of larval food resources and adult movement in the population dynamics of the orange-tip butterfly (Anthocharis cardamines). Oecologia 111:549-556 
Dobkin D, Olivieri I, Ehrlich P (1987) Rainfall and the interaction of microclimate with larval resources in the population dynamics of checkerspot butterflies (Euphydryas editha) inhabiting serpentine grassland. Oecologia 71:161-166

Dowdeswell WH, Fisher R, Ford EB (1940) The quantitative study of populations in the lepidoptera I. Polyommatus icarus rott. Ann Eugenic 10:123-136

EEA (2011) Are Lepidoptera an effective 'umbrella group' for biodiversity conservation? Publications Office of the European Union, Belgium

Fagerström T, Wiklund C (1982) Why do males emerge before females? Protandry as a mating strategy in male and female butterflies. Oecologia 52:164-166

Fischer K (1998) Population structure, mobility and habitat selection of the butterfly Lycaena hippothoe (Lycaenidae: Lycaenini) in western Germany. Nota Lepidopterologica 21:14-30

Fischer K, Fiedler K (2001) Resource-based territoriality in the butterfly Lycaena hippothoe and environmentally induced behavioural shifts. Anim Behav 61:723-732

Fischer K, Beinlich B, Plachter H (1999) Population structure, mobility and habitat preferences of the violet copper Lycaena helle (Lepidoptera: Lyceanidae) in Western Germany: implications for conservation. J Insect Conserv 3:43-52

Fischer K, Bot A, Brakefield P, Zwaan BJ (2006) Do mothers producing large offspring have to sacrifice fecundity? J Evol Biol 19:380-391

Fjellstad WJ (1998) The landscape ecology of butterflies in traditionally managed Norwegian farmland. Dissertation, University of Durham

Fontaine B et al (2007) The European union's 2010 target: putting rare species in focus. Biol Conserv 139:167-185

Franzén M, Johannesson M (2007) Predicting extinction risk of butterflies and moths (Macrolepidoptera) from distribution patterns and species characteristics. J Insect Conserv 11:367-390

Fred MS, O'Hara RB, Brommer JE (2006) Consequences of the spatial configuration of resources for the distribution and dynamics of the endangered Parnassius apollo butterfly. Biol Conserv 130:183-192

Friberg M, Bergman M, Kullberg J, Wahlberg N, Wiklund C (2008) Niche separation in space and time between two sympatric sister species-a case of ecological pleiotropy. Evol Ecol 22:1-18

Fric Z, Hula V, Klimová M, Zimmermann K, Konvička M (2010) Dispersal of four fritillary butterflies within identical landscape. Ecol Res 25:543-552

Gibbs KE, Siebenmann M (1996) Life history attributes of the rare mayfly Siphlonisca aerodromia Needham (Ephemeroptera: Siphlonuridae). J N Am Benthol Soc 15:95-105

Haaland C (2015) Abundances and movement of the Scarce Copper butterfly (Lycaena virgaureae) on future building sites at a settlement fringe in southern Sweden. J Insect Conserv 19:255-264

Habel JC, Segerer A, Ulrich W, Torchyk O, Weisser WW, Schmitt T (2015) Butterfly community shifts over 2 centuries. Conserv Biol 135:648-656

Haeler E, Fiedler K, Grill A (2014) What prolongs a butterfly's life?: trade-offs between dormancy, fecundity and body size. PloS One 9:e111955

Hanski I, Alho J, Moilanen A (2000) Estimating the parameters of survival and migration of individuals in metapopulations. Ecology $81: 239-251$

Hanski I, Saastamoinen M, Ovaskainen O (2006) Dispersal-related life-history trade-offs in a butterfly metapopulation. J Anim Ecol 75:91-100

Harker RJ, Shreeve TG (2008) How accurate are single site transect data for monitoring butterfly trends? Spatial and temporal issues identified in monitoring Lasiommata megera. J Insect Conserv 12:125-133

Heer P, Pellet J, Sierro A, Arlettaz R (2013) Evidence-based assessment of butterfly habitat restoration to enhance management practices. Biodivers Conserv 22:239-252

Hernandez-Roldan JL, Munguira ML, Martin J (2009) Ecology of a relict population of the vulnerable butterfly Pyrgus sidae on the Iberian Peninsula (Lepidoptera: Hesperiidae). Eur J Entomol 106:611-618

Hill WG (1972) Effective size of populations with overlapping generations. Theor Popul Biol 3:278-289

Hodgson JG (1993) Commonness and rarity in British butterflies. J Appl Ecol 30:407-427

Kajzer-Bonk J, Nowicki P, Bonk M, Skórka P, Witek M, Woyciechowski M (2013) Local populations of endangered Maculinea (Phengaris) butterflies are flood resistant. J Insect Conserv 17:1105-1112

Karlsson B, Wiklund C (2005) Butterfly life history and temperature adaptations; dry open habitats select for increased fecundity and longevity. J Anim Ecol 74:99-104

Komonen A, Grapputo A, Kaitala V, Kotiaho JS, Päivinen J (2004) The role of niche breadth, resource availability and range position on the life history of butterflies. Oikos 105:41-54

Konvička M, Kuras T (1999) Population structure, behaviour and selection of oviposition sites of an endangered butterfly, Parnassius Mnemosyne, in Litovelské Pomoraví. Czech Republic. J Insect Conserv 3:211-223

Konvička M, Nedvěd O, Fric Z (2002) Early-spring floods decrease the survival of hibernating larvae of a wetland-inhabiting population of Neptis rivularis (Lepidoptera: Nymphalidae). Acta Zool Hung 48:79-88

Konvička M et al (2005) For whom the bells toll: Demography of the last population of the butterfly Euphydryas maturna in the Czech Republic. Biologia 60:551-557

Kotiaho JS, Kaitala V, Komonen A, Päivinen J (2005) Predicting the risk of extinction from shared ecological characteristics. P Natl Acad Sci USA 102:1963-1967

Lande R, Barrowclough GF (1987) Effective population size, genetic variation, and their use in population management. Viable Populations for Conservation:87-123

Lessells CM, Boag PT (1987) Unrepeatable repeatabilities: a common mistake. Auk 104:116-121

Lewis OT et al. (1997) Three ways of assessing metapopulation structure in the butterfly Plebejus argus. Ecol Entomol 22:283-293

Longcore T, Mattoni R, Zonneveld C, Bruggeman J (2003) INsect Count Analyzer: A tool to assess responses of butterflies to habitat restoration. Ecol Restor 21:60-61

Lörtscher M, Erhardt A, Zettel J (1997) Local movement patterns of three common grassland butterflies in a traditionally managed landscape. M Sch Entomol Gesell 70:43-56

Magnus D (1954) Methodik und Ergebnisse einer Populations markierung des Kaisermantels. Dtsch Ent Tag Hamburg 1953:187-197

Margules CR, Pressey RL (2000) Systematic conservation planning. Nature 405:243-253

Martins EP, Hansen TF (1996) The statistical analysis of interspecific data: a review and evaluation of phylogenetic comparative methods. In: Martins E (ed) Phylogenies and the comparative method in animal behaviour. Oxford University Press, New York, Oxford, pp 22-75

Mattila N, Kaitala V, Komonen A, Kotiaho JS, Paeivinen J (2006) Ecological determinants of distribution decline and risk of extinction in moths. Conserv Biol 20:1161-1168

Morbey YE, Ydenberg RC (2001) Protandrous arrival timing to breeding areas: a review. Ecol Lett 4:663-673 
Morton A (1985) The population biology of an insect with a restricted distribution: Cupido minimus Fuessly (Lepidoptera: Lycaenidae). Dissertation, University of Southampton

Müller F, Baessler C, Schubert H, Klotz S (2010) Long-term ecological research. Springer, Berlin

Munguira ML, Martín J, García-Barros E, Viejo JL (1997) Use of space and resources in a Mediterranean population of the butterfly Euphydryas aurinia. Acta Oecol 18:597-612

Nabielec J, Nowicki P (2015) Drivers of local densities of endangered Lycaena helle butterflies in a fragmented landscape. Popul Ecol 57:649-656

Niitepõld K, Hanski I (2013) A long life in the fast lane: positive association between peak metabolic rate and lifespan in a butterfly. J Exp Biol 216:1388-1397

Novacek MJ, Cleland EE (2001) The current biodiversity extinction event: scenarios for mitigation and recovery. P Natl A Sci 98:5466-5470

Nowicki P et al (2005a) Less input same output: simplified approach for population size assessment in Lepidoptera. Popul Ecol 47:203-212

Nowicki P, Witek M, Skorka P, Settele J, Woyciechowski M (2005b) Population ecology of the endangered butterflies Maculinea teleius and M. nausithous and the implications for conservation. Popul Ecol 47:193-202

Nowicki P, Settele J, Henry P-Y, Woyciechowski M (2008) Butterfly monitoring methods: the ideal and the real world. Isr J Ecol Evol 54:69-88

Nowicki P, Bonelli S, Barbero F, Balletto E (2009) Relative importance of density-dependent regulation and environmental stochasticity for butterfly population dynamics. Oecologia 161:227-239

Nowicki P, Vrabec V, Binzenhöfer B, Feil J, Zakšek B, Hovestadt T, Settele J (2014) Butterfly dispersal in inhospitable matrix: rare, risky, but long-distance. Landscape Ecol 29:401-412

Nowicki P, Marczyk J, Kajzer-Bonk J (2015) Metapopulations of endangered Maculinea butterflies are resilient to large-scale fire. Ecohydrology 8:398-405

Nylin S, Bergström A (2009) Threat status in butterflies and its ecological correlates: how far can we generalize? Biodivers Conserv 18:3243-3267

Örvössy N, Kőrösi Á, Vozár Á, Batáry P, Peregovits L (2005) Microhabitat preference of the Southern Festoon (Zerynthia polyxena). In: Kühn E, Feldmann R, Thomas J, Settele J (eds) Studies on the ecology and conservation of butterflies in Europe. Leipzig - Halle. Pensoft, Sofia - Moscow, pp 24-25

Örvössy N, Kőrösi Á, Batáry P, Vozár A, Peregovits L (2013) Potential metapopulation structure and the effects of habitat quality on population size of the endangered False Ringlet butterfly. J Insect Conserv 17:537-547

Parr M, Gaskell T, George B (1968) Capture-recapture methods of estimating animal numbers. J Biol Educ 2:95-117

Pecsenye K, Bereczki J, Tihanyi B, Toth A, Peregovits L, Varga Z (2007) Genetic differentiation among the Maculinea species (Lepidoptera: Lycaenidae) in eastern Central Europe. Biol J Linn Soc 91:11-21

Pellet J, Gander A (2009) Comparaison de méthodes pour l'estimation de l'abondance des populations de papillons de jour: établissement d'un protocole de suivi du Grand Negre des bois Minois dryas sur la rive sud du lac de Neuchâtel. Entomo Helvetica 2:201-216

Pennekamp F, Garcia-Pereira P, Schmitt T (2014) Habitat requirements and dispersal ability of the Spanish Fritillary (Euphydryas desfontainii) in southern Portugal: evidence-based conservation suggestions for an endangered taxon. J Insect Conserv $18: 497-508$
Petit S, Moilanen A, Hanski I, Baguette M (2001) Metapopulation dynamics of the bog fritillary butterfly: movements between habitat patches. Oikos 92:491-500

Pfeifer M, Andrick U, Frey W, Settele J (2000) On the ethology and ecology of a small and isolated population of the Dusky Large Blue Butterfly Glaucopsyche (Maculinea) nausithous (Lycaenidae). Nota Lepidopterologica 23:147-172

Pfeifer MA, Henle K, Settele J (2007) Populations with explicit borders in space and time: concept, terminology, and estimation of characteristic parameters. Acta Biotheor 55:305-316

Pijpe $\mathbf{J}$ (2007) The evolution of lifespan in the butterfly Bicycus anynana. Dissertation, University of Leiden

Purvis A, Gittleman JL, Cowlishaw G, Mace GM (2000) Predicting extinction risk in declining species. P Roy Soc Lond B Bio 267:1947-1952

Rabasa SG, David Gutierrez D, Escudero A (2005) Egg laying by a butterfly on a fragmented host plant: a multi-level approach. Ecography 28:629-639

Rabasa SG, David Gutierrez D, Escudero A (2007) Metapopulation structure and habitat quality in modelling dispersal in the butterfly Iolana iolas. Oikos 116:793-806

Reymond A (2014) Ecology and conservation of a Violet Copper (Lycaena helle) metapopulation. Master Thesis, University of Lausanne

Robinet C, Roques A (2010) Direct impacts of recent climate warming on insect populations. Integ Zool 5:132-142

Schmidt A (1989) Die Großschmetterlinge des Vogelsberges. Untersuchungen zur Ökologie und Faunistik der Großschmetterlinge (Makrolepidoptera) des Vogelsberges unter besonderer. Das Künanzhaus Suppl 3:1-210

Schmitt T et al (2006) The Chalk-hill Blue Polyommatus coridon (Lycaenidae, Lepidoptera) in a highly fragmented landscape: How sedentary is a sedentary butterfly? J Insect Conserv $10: 311-316$

Schtickzelle N, Le Boulengé E, Baguette M (2002) Metapopulation dynamics of the bog fritillary butterfly: demographic processes in a patchy population. Oikos 97:349-360

Schtickzelle N, Choutt J, Goffart P, Fichefet V, Baguette M (2005) Metapopulation dynamics and conservation of the marsh fritillary butterfly: population viability analysis and management options for a critically endangered species in Western Europe. Biol Conserv 126:569-581

Scott JA (1973) Lifespan of butterflies. J Res Lepid 12:225-230

Settele J, Feldmann R, Reinhardt R (1999) Die Tagfalter Deutschlands. Ulmer Stuttgart

Seufert W (1990) Untersuchungen zur Ökologie des Schwarzen Apollo (Parnassius mnemosyne L.; Lepidoptera: Papilionidae) in der Rhön. Dissertation, University of Würzburg

Seufert P (1993) Grundlagen zum Schutz der Tagfalter (Lepidoptera: Papilionoidea, Hesperioidea) in Naturschutzgebied "Mäusberg" (Landkr. Main-Spessart). Abh Naturwiss Ver Würzburg 34:75-104

Sielezniew M, Rutkowski R, Ponikwicka-Tyszko D, Ratkiewicz M, Dziekańska I, Švitra G (2012) Differences in genetic variability between two ecotypes of the endangered myrmecophilous butterfly Phengaris (=Maculinea) alcon - the setting of conservation priorities. Insect Conserv Diver 5:223-236

Slámova I, Klečka J, Konvička M (2013) Woodland and grassland mosaic from a butterfly perspective: habitat use by Erebia aethiops (Lepidoptera: Satyridae). Insect Conserv Diver 6:243-254

Soulsby RL, Thomas JA (2012) Insect population curves: modelling and application to butterfly transect data. Meth Ecol Evol 3:832-841

Stanish W, Taylor N (1983) Estimation of the intraclass correlation coefficient for the analysis of covariance model. Am Stat $37: 221-224$ 
Statzner B, Hildrew AG, Resh VH (2001) Species traits and environmental constraints: entomological research and the history of ecological theory. Annu Rev Ecol 46:291-316

Steiner F, Schlick-Steiner B, Höttinger H, Nikiforov A, Moder K, Christian E (2005) Maculinea alcon and M. rebeli (Insecta: Lepidoptera: Lycaenidae)-one or two alcon blues? Larval cuticular compounds and egg morphology of East Austrian populations. Annalen des Naturhistorischen Museums in Wien. Serie B für Botanik und Zoologie:165-180

Streitberger M, Hermann G, Kraus W, Fartmann T (2012) Modern forest management and the decline of the Woodland Brown (Lopinga achine) in Central Europe. Forest Ecol Manag 269:239-248

Sutcliffe OL, Thomas CD, Peggie D (1997) Area-dependent migration by ringlet butterflies generates a mixture of patchy population and metapopulation attributes. Oecologia 109:229-234

Szentirmai I, Mesterházy A, Varga I, Schubert Z, Sándor LC, Ábrahám L, Kőrösi Á (2014) Habitat use and population biology of the Danube Clouded Yellow butterfly Colias myrmidone (Lepidoptera: Pieridae) in Romania. J Insect Conserv $18: 417-425$

Takemon Y (2000) Reproductive behavior and morphology of Paraleptophlebia spinosa (Ephemeroptera: Leptophlebiidae): implications of variation in copula duration. Limnology 1:47-56

Tartally A, Nash DR, Lengyel S, Varga Z (2008) Patterns of host ant use by sympatric populations of Maculinea alcon and $M$. "rebeli" in the Carpathian Basin. Insect Soc 55:370-381

Thomas J (1983) The ecology and status of Thymelicus acteon (Lepidoptera: Hesperiidae) in Britain. Ecol Entomol 8:427-435

Thomas J (1995) The conservation of declining butterfly populations in Britain and Europe: priorities, problems and successes. Biol J Linn Soc 56:55-72

Thomas J et al (2004) Comparative losses of British butterflies, birds, and plants and the global extinction crisis. Science 303:1879-1881

Timuș N, Craioveanu C, Sitaru C, Rus A, Rákosy L (2013) Differences in adult phenology, demography, mobility and distribution in two syntopic ecotypes of Maculinea alcon (cruciata vs. pneumonanthe) (Lepidoptera: Lycaenidae) from Transilvania (Romania). Entomologica romanica 18:21-30

Tudor O, Parkin DT (1979) Studies on phenotypic variation in Maniola jurtina (Lepidoptera: Satyri-dae) in the Wyre forest, England. Heredity 42:91-104

Turlure C, Choutt J, Van Dyck H, Baguette M, Schtickzelle N (2010) Functional habitat area as a reliable proxy for population size: case study using two butterfly species of conservation concern. J Insect Conserv 14:379-388

Turlure C, Van Dyck H, Goffart P, Schtickzelle N (2014) Resourcebased habitat use in Lycaena helle: Significance of a functional, ecological niche-oriented approach. In: Habel JCh (ed) Jewels In The Mist: a synopsis on the highly endangered butterfly species the Violet Copper, Lycaena helle, 1st edn. Pensoft Publishers, Bulgaria, pp 67-86

Turner J (1963) A quantitative study of a Welsh colony of the large heath butterfly, Coenonympha tullia Müller (Lepidoptera). In: Proceedings of the Royal Entomological Society of London. Series A, General Entomology, vol 7-9. Wiley Online Library, pp 101-112

van Swaay C (2002) The importance of calcareous grasslands for butterflies in Europe. Biol Conserv 104:315-318 van Swaay C, Nowicki P, Settele J, van Strien AJ (2008) Butterfly monitoring in Europe: methods, applications and perspectives. Biodivers Conserv 17:3455-3469

van Swaay C et al. (2010) European red list of butterflies. Publications Office of the European Union, Luxembourg

Vodă R, Timuş N, Paulini I, Popa R, Mihali C, Crişan A, Rákosy L (2010) Demographic parameters of two sympatric Maculinea species in a Romanian site (Lepidoptera: Lycaenidae). Entomologica romanica 15:25-32

Vogel K, Johannesen J (1996) Research on population viability of Melitaea didyma (Esper, 1779)(Lepidoptera, Nymphalidae). Species Survival Fragmented Landscapes 35:262-267

Wahlberg N, Klemetti T, Selonen V, Hanski I (2002) Metapopulation structure and movements in five species of checkerspot butterflies. Oecologia 130:33-43

WallisDeVries MF (2004) A quantitative conservation approach for the endangered butterfly Maculinea alcon. Conserv Biol 18:489-499

Warren M (1987) The ecology and conservation of the heath fritillary butterfly, Mellicta athalia. II. Adult population structure and mobility. J Appl Ecol 24:483-498

Warren MS (1992) Butterfly populations. In: Dennis RLH. The ecology of butterflies in Britain. 1st (ed). Oxford University Press, Oxford, pp 73-92

Warren MS, Bourn NA (2011) Ten challenges for 2010 and beyond to conserve Lepidoptera in Europe. J Insect Conserv 15:321-326

Warren M, Pollard E, Bibby T (1986) Annual and long-term changes in a population of the wood white butterfly Leptidea sinapis. $\mathrm{J}$ Anim Ecol 55:707-719

Wenzel M, Schmitt T, Weitzel M, Seitz A (2006) The severe decline of butterflies on western German calcareous grasslands during the last 30 years: a conservation problem. Biol Conserv 128:542-552

Wickman PC (1985) The influence of temperature on the territorial and mate locating behaviour of the small heath butterfly, Coenonympha pamphilus (L.) (Lepidoptera: Satyridae). Behav Ecol Sociobiol 16:233-238

Wiklund C, Fagerström T (1977) Why do males emerge before females? Oecologia 31:153-158

Zimmermann K, Fric Z, Filipová L, Konvička M (2005) Adult demography, dispersal and behaviour of Brenthis ino (Lepidoptera: Nymphalidae): how to be a successful wetland butterfly. Eur J Entomol 102:699-706

Zimmermann K, Konvička M, Fric Z, Čihaková V (2009) Demography of a common butterfly on humid grasslands: Argynnis aglaja (Lepidoptera: Nymphalidae) studied by mark-recapture. Pol J Ecol 57:715-727

Zimmermann K et al (2011) Demography of adults of the Marsh fritillary butterfly, Euphydryas aurinia (Lepidoptera: Nymphalidae) in the Czech Republic: Patterns across sites and seasons. Eur J Entomol 108:243-254

Zonneveld C (1991) Estimating death rates from transect counts. Ecol Entomol 16:115-121

Zonneveld C (1992) Polyandry and protandry in butterflies. B Math Biol 54:957-976

Zonneveld C, Metz J (1991) Models on butterfly protandry: virgin females are at risk to die. Theor Popul Biol 40:308-321 